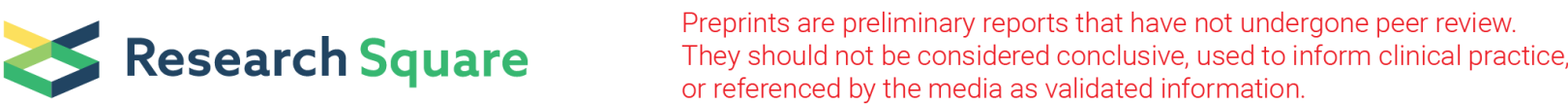

\section{Assessment of the YKL-40 concentration in patients with tick-borne encephalitis}

\section{Piotr Czupryna}

Medical University of Bialystok: Uniwersytet Medyczny w Bialymstoku

\section{Agnieszka Kulczyńska-Przybik}

Medical University of Bialystok: Uniwersytet Medyczny w Bialymstoku

\section{Barbara Mroczko}

Medical University of Bialystok: Uniwersytet Medyczny w Bialymstoku

\section{Mulugeta Wondim}

Medical University of Bialystok: Uniwersytet Medyczny w Bialymstoku

\section{Sambor Grygorczuk}

Medical University of Bialystok: Uniwersytet Medyczny w Bialymstoku

\section{Karol Borawski}

Medical University of Bialystok: Uniwersytet Medyczny w Bialymstoku

\section{Sławomir Pancewicz}

Medical University of Bialystok: Uniwersytet Medyczny w Bialymstoku

Anna Moniuszko-Malinowska ( $\square$ annamoniuszko@op.pl)

Medical University of Bialystok: Uniwersytet Medyczny w Bialymstoku https://orcid.org/0000-00023994-8785

\section{Research}

Keywords: TBE, neurodegeneration, YKL-40

Posted Date: March 2nd, 2021

DOl: https://doi.org/10.21203/rs.3.rs-135104/v2

License: (c) This work is licensed under a Creative Commons Attribution 4.0 International License.

Read Full License

Version of Record: A version of this preprint was published at Ticks and Tick-borne Diseases on January 1st, 2022. See the published version at https://doi.org/10.1016/j.ttbdis.2022.101895. 


\section{Abstract \\ Background}

Tick-Borne Encephalitis (TBE) is a viral infection of the Central Nervous System (CNS) caused by TickBorne Encephalitis Virus (TBEV). It might take several clinical courses such as: meningitis, meningoencephalitis or meningoencephalomyelitis. The aim this study was to compare the YKL-40 concentration in cerebrospinal fluid (CSF) of patients with different clinical presentations of TBE and patients with excluded meningitis (control group).

\section{Methods}

The concentration of YKL-40 in CSF was determined using Fujirebio tests (Ghent, Belgium) in 32 patients with TBE: group I-patients with meningoencephalitis $(n=16)$; group II-patients with meningitis $(n=16)$. The control group (CG) consisted of 17 patients in whom inflammatory process in central nervous system was excluded.

\section{Results}

The concentration of YKL-40 was significantly higher in encephalitis group than in CG after 7 days from the last dose of treatment. The concentration in patients with neuroinflammation had significantly different concentration of YKL-40 compared to patients with no neuroinflammation control groups. ROC curve analysis indicates that: CSF YKL-40 concentration at cut off 783.87 differentiated TBE patients from CG with $100 \%$ specificity and 70\% sensitivity and CSF YKL-40 concentration at cut off 980.11 differentiated meningitis from meningoencephalitis with $87.5 \%$ specificity and $62.5 \%$ sensitivity.

\section{Conclusions}

YKL-40 takes part in TBE pathogenesis, its concentration is the highest at the early stage of Central Nervous System involvement and decreases in the convalescent period. As YKL-40 is significantly higher in meningitis than in meningoencephalitis, it might be used as biomarker in differentiation of these clinical forms of TBE.

\section{Introduction}

Tick-Borne Encephalitis (TBE) is a viral infection of the Central Nervous System (CNS) caused by TickBorne Encephalitis Virus (TBEV) transmitted by Ixodide tick bite that might lead to severe sequelae [1, 2]. The annual incidence of TBE in Poland is $200-300$ with $90 \%$ of them are from two regions of the two northeastern provinces of the country [3]. In years 2000-2015, 3662 cases were reported in Poland at 
country level where $45 \%$ of them were from the Podlaskie province(the place where this study is conducted) [4].

The clinical features of TBE elapse from asymptomatic to cognitive and neurologic impairments. It could appear as meningitis, meningoencephalitis, and meningoencephalomyelitis [5]. According to various reports $20-58 \%$ of patients may develop sequelae after TBE (mild, moderate or severe) while others completely recover from their illness without indications of sequelae $[6,7]$.

Is has been proven that some neurodegenerative diseases such as Alzheimer's Disease (AD) might be induced by infectious diseases [8, 9]. In two previous studies conducted in the same institution we have observed that Neuron Specific Enolase (NSE) and tau protein were increased in cerebrospinal fluid (CSF) $[10,11]$ which suggested that TBE may lead to neurodegeneration.

Therefore we wanted to assess whether other markers of neurodegeneration also take part in the pathogenesis of TBE. We decided to choose YKL-40 (chitinase-3 like-1 [CHI3L1]) a member of the family 18 glycosyl hydrolases, secreted by activated neutrophils and macrophages. In the central nervous system (CNS), YKL-40 is mostly expressed by microglia, especially when responding to acute and chronic inflammation $[12,13,14]$.

The aim this study was to assess of the YKL-40 concentration in CSF of patients with different encephalitis and meningitis associated with TBE.

This study has the following specific objectives:

- Evaluation of YKL-40 concentration in patients with TBE in cerebrospinal fluid before and after treatment

- Comparison of YKL-40 concentration in patients with TBE and patients with excluded meningitis

- Comparison of YKL-40 concentration in patients with meningoencephalitis and meningitis

- Comparison of YKL-40 concentration in patients with and without sequalae

\section{Material And Methods}

The concentration of YKL-40 in CSF was measured among patients treated for TBE in the department of Infectious Diseases and Neuroinfections of Medical University of Bialystok.

All patients treated during the time of the study were analyzed and divided into two groups based on their clinical diagnosis:

- Group I: patients with menigoencephalitis ( $n=16 ; 7$ women, 9 men ,mean age $54.5 \pm 8.93$ years). Meningoencephalitis was diagnosed when the inflammatory parameters in CSF, altered consciousness and focal neurological symptoms were present. 
- Group II: Patients with meningitis ( $n=16: 6$ women and 10 men, mean age $56.7 \pm 10.46$ years). Meningitis was diagnosed on the basis of inflammatory parameters in CSF with no focal neurological symptoms.

During this study, no patient was hospitalized due to meningoencephalomyelitis.

None of the participants were vaccinated for TBE. TBE was diagnosed based on the clinical picture, presence of inflammatory parameters in the CSF, and specific antibodies present in serum and CSF. TBE antibody titer was measured with Enzygnost Anti-TBE/FSME Virus (IgG, IgM) Siemens test. A case of TBE was diagnosed according to EAN rules [15]. No patient had a history of any neurodegenerative disorder that could have effect to the result of the study. Patients were treated with $0.25 \mathrm{~g} / \mathrm{kg} 15 \%$ Mannitol per dose 2-4 times a day and, if needed, NSAIDs (ketoprofenum) was also administered. The treatment lasted for 4-7 days and the effect of treatment on the study was considered by collecting sample 1 before treatment initiated and sample 2 taken after seven days after drug withdrawal.

The control group (CG) consisted of 17 patients ( 6 women, 11 men, mean age $50.1 \pm 10.39$ years). These group of patients were admitted to the hospital with a compliant of headache with a ruled out CSF inflammatory process (mean cytosis $-3,4 \pm 1.804$ cells $/ \mu \mathrm{L}$; protein concentration $-36,67 \pm 10.66 \mathrm{mg} / \mathrm{dL}$ ). They also had no history of neurodegenerative disorders.

The concentration of YKL-40 (ng/ml) in CSF was determined using Fujirebio test (Ghent, Belgium). YKL40 concentration in CSF was measured on admission (Sample 1) and 14 days after admission or seven days after drug withdrawal (Sample 2). The ratio of sample 2 against sample 1(YKL 2/YKL 1) was also calculated to identify the effect of treatment on YKL-40. As a follow up, patients were examined for the presence of sequelae in the outpatients department.

Patients voluntarily agreed to participate in the study and gave their written informed consent.

The study was approved by the Local Bioethics Committee of the Medical University of Bialystok.

The statistical analysis was performed using STATISTICA 10. Groups were compared with Mann-Whitney $\mathrm{U}$ test, Wilcoxon-matched pair test and receiver operating characteristic curve (ROC) tests. Correlations were measured by the Spearman rank test.

\section{Results}

The main complains reported by TBE patients were headache 30/32 patients, fever 29/32 patients, nausea $12 / 32$ patients, vertigo $8 / 32$ patients, vomits $3 / 32$ patients.

Patients diagnosed with meningitis had no focal neurological symptoms. All patients diagnosed with meningoencephalitis presented with consciousness disturbances. The main neurological symptoms in this group were: ataxia $6 / 16$ patients, tremor $5 / 16$ patients, paresis $4 / 16$ patients, pyramidal symptoms $1 / 16$ patients. 
The laboratory parameters of patients are presented in Table 1.

Table 1

The laboratory parameters of patients included to the study

\begin{tabular}{|lllll|}
\hline & \multicolumn{2}{l}{ Encephalitis } & \multicolumn{2}{l|}{ Meningitis } \\
\hline Variable & Mean & SD & Mean & SD \\
\hline WBC (x 109/per microliter) & 8.48 & 3.5 & 9.18 & 3.007 \\
\hline CRP (mg/dl) & 5.35 & 6.125 & 5.51 & 8.424 \\
\hline AST (IU/L) & 26.93 & 12.929 & 24.75 & 17.613 \\
\hline ALT (IU/L) & 46.93 & 42.433 & 34.33 & 28.404 \\
\hline CSF I - cytosis (cells/ $\mu \mathrm{L})$ & 137.63 & 147.872 & 115.93 & 83.244 \\
\hline CSF I - polynuclear cells (cells/ $\mu \mathrm{L})$ & 69.25 & 151.195 & 54.4 & 60.422 \\
\hline CSF I - protein (mg/dL) & 60.19 & 22.466 & 73.94 & 28.707 \\
\hline CSF II - cytosis (cells/ $\mu \mathrm{L})$ & 23.71 & 21.670 & 44.25 & 24.981 \\
\hline CSF II - polynuclear cells (cells/ $\mu \mathrm{L})$ & 3.0 & 3.549 & 3.4 & 4.623 \\
\hline CSF II - protein (mg/dL) & 67.64 & 54.272 & 75.09 & 41.965 \\
\hline
\end{tabular}

8/32 patients developed sequelae - mild cognitive disorders and persistent headache -4 patients, paresis - 4 patients.

Mean YKL-40 concentration in CSF in sample 1 was significantly higher in both examined groups (Group I and II) than in CG $(p<0.05)$. It was also significantly higher in Group II than in Group I $(p<0.05)($ Table 2). 
Table 2

Concentration of YKL-40 in serum and CSF of patients with TBE in the form of encephalitis (Group I) and meningitis (Group II) before (Sample 1) and after treatment (Sample 2)

\begin{tabular}{|c|c|c|c|c|c|c|}
\hline & $\begin{array}{l}\text { Sample } 1 \text { Mean } \pm \\
\text { SD YKL-40 } \\
(\mathrm{ng} / \mathrm{ml})\end{array}$ & & $\begin{array}{l}\text { Sample } 2 \text { Mean } \pm \\
\text { SD YKL-40 } \\
(\mathrm{ng} / \mathrm{ml})\end{array}$ & & $\begin{array}{l}\text { p Sample } 1 \\
\text { vs Sample } \\
2\end{array}$ & \\
\hline & serum & CSF & serum & CSF & serum & CSF \\
\hline TBE & $102.38 \pm 63.2$ & $\begin{array}{l}1475.37 \\
\pm 913.86\end{array}$ & $100.73 \pm 84.96$ & $\begin{array}{l}827.68 \\
\pm \\
529.71\end{array}$ & $\mathrm{~s}$ & $\begin{array}{l}<.05 \\
0.05\end{array}$ \\
\hline Group I & $103.22 \pm 80.95$ & $\begin{array}{l}1190.58 \\
\pm 982.51\end{array}$ & $99.99 \pm 112.09$ & $\begin{array}{l}774.5 \\
\pm 632.5\end{array}$ & ns & ns \\
\hline Group II & $101.54 \pm 41.24$ & $\begin{array}{l}1760.149 \\
\pm 766.545\end{array}$ & $101.48 \pm 48.5$ & $\begin{array}{l}880.87 \\
\pm \\
416.91\end{array}$ & ns & $\begin{array}{l}<.05 \\
0.05\end{array}$ \\
\hline CG & $91.39 \pm 62.43$ & $\begin{array}{l}311.53 \pm \\
240.59\end{array}$ & & & & \\
\hline $\begin{array}{l}\text { p Group I } \\
\text { vs. Group } \\
\text { II }\end{array}$ & ns & $<0.05$ & ns & ns & & \\
\hline $\begin{array}{l}\text { p Group I } \\
\text { vs. CG }\end{array}$ & ns & $<0.05$ & & & & \\
\hline $\begin{array}{l}\text { P Group II } \\
\text { vs. CG }\end{array}$ & ns & $<0.05$ & & & & \\
\hline
\end{tabular}

ROC curve analysis indicates that YKL-40 protein concentration in CSF differentiates TBE patients from CG. At the cut-off at $783.87 \mathrm{ng} / \mathrm{ml}$ specificity is $100 \%$ and sensitivity $75 \%$. AUC $=0.915, \mathrm{p}<0.05$ (Fig. 1).

ROC curve analysis indicates that YKL-40 protein concentration in CSF differentiates meningitis and meningoencephalitis. At the cut-off $980.11 \mathrm{ng} / \mathrm{ml}$ specificity is $87.5 \%$ and sensitivity $62.5 \%$ AUC $=0.711$, $\mathrm{p}<0.05$ (Fig. 2).

Serum concentration of YKL-40 did not differ in Sample 1 and 2 neither in meningitis nor in meningoencephalitis group.

CSF concentration of YKL-40 measured in sample 2 was significantly lower $(p<0.05)$ than in sample 1 in meningitis group while in meningoencephalitis group the result was nonsignificant.

The serum YKL-40 ratio in Group I was $1.23 \pm 0.62 \mathrm{ng} / \mathrm{ml}$ and in Group II $1.11 \pm 0.4 \mathrm{ng} / \mathrm{ml}$. The result was non-significant.

The CSF YKL-40 ratio in Group I was significantly lower than in Group II $(2.1 \pm 2.13$ vs $2.2 \pm 0.79 \mathrm{ng} / \mathrm{ml} \mathrm{p}$ $<0.05)$. 
Comparison of sequelae group and other TBE patients did not show any statistically significant difference as far as YKL-40 concentrations in serum and CSF are concerned.

In the whole TBE group correlation between YKL-40 concentration and CSF protein concentration was observed (Sample 1: $R=0.39 p<0.05$, Sample $2-R=0.59 p<0.05$ ). Also $Y K L-40$ serum concentration in Sample I correlated with WBC count at admission $(R=0.41 p<0.05)$. YKL-40 CSF concentration correlated with neutrophils count in Sample 1 (Sample 1: $R=0.57 p<0.05$ ) and lymphocyte count in both samples (Sample 1: $R=0.62$, Sample 2: $R=0.46 p<0.05$ ).

\section{Discussion}

In our previous studies we reported that TBE may lead to neurodegeneration. First of all we observed that patients with a history of TBE in MRI present with cerebral atrophic lesions that cannot be explained by age [16]. Also we found out that several neurodegeneration markers are increased in TBE patients. Neuron-specific enolase (NSE) concentration in CSF of patients with meningoencephalitis was significantly higher than in controls and in patients with meningitis. What is more NSE concentration in the CSF was higher in sample 2 than in sample 1 which implied that neurodegenerative processes were ongoing even after clinical recovery [11].

The same phenomenon was stated in our another study concerning Tau protein in the CSF of TBE patients. Additionally we observed that Tau protein concentration might be a predictor of sequelae development in the course of TBE [10].

In the current study we evaluated the usefulness of another well-known neurodegeneration biomarker YKL-40 protein. Contrary to NSE and Tau protein, YKL-40 concentration was the highest the beginning of the disease and decreased in the recovery phase. What is even more interesting it was significantly higher in the meningitis group, usually associated with mild course of the disease.

YKL-40 seems not very useful for prognosis of sequelae development as both serum and CSF concentrations were comparable in patients who recovered completely and those who presented with persisting symptoms.

This is in disagreement to most reports that associate YKL-40 concentration increase with unfavorable course of many diseases.

According to the literature YKL-40 proved to be a promising biomarker in various diseases.

High concentrations of YKL-40 in serum are correlated to morbidity of such different diseases as community-acquired pneumonia, active rheumatoid arthritis, and ongoing hepatic fibrosis, as well as to mortality of recurrent breast cancer and colorectal cancer $[12,17,18,19,20,21]$. It has been proven that this protein takes part in Alzheimer disease development and can be used in prediction of dementia development risk among cognitively normal subjects [13] and for prognosis in NMDR encephalitis [14]. 
Østergaard et al. reported that Increased concentrations of YKL-40 were found in patients with purulent meningitis [12]. The authors did not find any clear correlations with severe outcome or mortality. However they observed that YKL-40 CSF concentration correlated with neutrophils and lymphocyte count. This is in accordance with our study. In TBE neutrophils number in CSF is usually elevated at the early stage of CNS infection while at the later stage of the disease lymphocytes predominate.

Neutrophils migrate into CSF of patients with TBE independently of the lymphocyte influx and BBB disruption. Of chemokines attracting neutrophils at least IL-8 and CXCL1 create chemotactic gradients towards CSF and may be responsible for neutrophil recruitment, and CXCL1 concentration correlates with CSF neutrophil count and with encephalitic presentation [22]. This would partially explain the increased concentration of YKL-40 in CSF Sample 1. However as the neutrophil count was higher in meningoencephalitis group, some other mechanisms of YKL-40 release to CSF have to be involved. Also the connection between lymphocytes and YKL-40 is unknown.

The results of our study should be interpreted with special care. The examined group was relatively small and no patients with the most severe form of TBE - meningoencephalomyelitis were hospitalized at the time of the study. Also limited funding of the study did not allow us to correlate YKL-40 concentrations with other markers of neurodegeneration.

\section{Conclusions}

YKL-40 takes part in TBE pathogenesis, its concentration is the highest at the early stage of Central Nervous System involvement and decreases in the convalescent period.

As YKL-40 is significantly higher in meningitis than in meningoencephalitis, it might be used as biomarker in differentiation of these clinical forms of TBE.

\section{Declarations}

Ethical Approval and Consent to participate: Patients voluntarily agreed to participate in the study and gave their written informed consent. The study was approved by Local Ethical Committee.

Consent for publication: All authors declare their consent for publication.

Availability of supporting data: Yes

Competing interests: Authors declare no conflict of interests.

Authors' contributions:

Piotr Czupryna: collection of samples, analysis of results, writing a manuscript, funding of analyses

Agnieszka Kulczyńska-Przybik: performance of analyses

Barbara Mroczko: performance of analyses 
Mulugeta Wondim: analysis of results

Sławomir Pancewicz: collection of samples

Sambor Grygorczuk: collection of samples

Karol Borawski: collection of samples

Anna Moniuszko-Malinowska: collection of samples, analysis of results, writing a manuscript, funding of analyses

Acknowledgements: Medical University of Bialystok, Poland

\section{Funding:}

Study was founded by Medical University of Bialystok obtained by Piotr Czupryna. Mulugeta Wondim is currently supported by a Marie Sklodowska-Curie Actions Early Career Research Fellowship (EU H2020 Grant agreement ID 754432).

\section{References}

1. Yoshii K. Epidemiology and pathological mechanisms of tick-borne encephalitis. J Vet Med Sci. 2019 Mar;81(3):343-7.

2. Deviatkin AA, Kholodilov IS, Vakulenko YA, Karganova GG, Lukashev AN. Tick-Borne Encephalitis Virus: An Emerging Ancient Zoonosis? Viruses. 2020; 23: 12(2).

3. European Centre for Disease Prevention and Control. Epidemiological situation of tick-borne encephalitis in the European Union and European Free Trade Association countries. LU: Publications Office; 2012 [cited 2020 Nov 17]. Available from: https://data.europa.eu/doi/10.2900/62311

4. Sadkowska-Todys M, Zieliński A, Czarkowski MP. Infectious diseases in Poland in 2017. Przegl Epidemiol. 2019; 73:135-50.

5. Bogovic P. Tick-borne encephalitis: A review of epidemiology, clinical characteristics, and management. WJCC. 2015;3(5):430-41.

6. Mickiene A, Laiskonis A, Günther G, Vene S, Lundkvist A, Lindquist L. Tickborne encephalitis in an area of high endemicity in lithuania: disease severity and long-term Clin Infect Dis. 2002;15:35(6):650-8.

7. Czupryna P, Grygorczuk S, Krawczuk K, Pancewicz S, Zajkowska J, Dunaj J, et al. Sequelae of tickborne encephalitis in retrospective analysis of 1072 patients. Epidemiology and Infection. 2018; 146(13): 1663-1670.

8. O'Connor SM, Taylor CE, Hughes JM. Emerging Infectious Determinants of Chronic Diseases. Emerg Infect Dis. 2006;12(7):1051-7. 
9. Marshall BJ, Armstrong JA, McGechie DB, Glancy RJ. Attempt to fulfil Koch's postulates for pyloric Campylobacter. Med J Aust. 1985; 5;142(8):436-9.

10. Czupryna P, Mroczko B, Pancewicz S, Muszynski P, Grygorczuk S, Dunaj J, et al. Assessment of the tau protein concentration in patients with tick-borne encephalitis. Eur J Clin Microbiol Infect Dis. 2019 Mar;38(3):479-483.

11. Czupryna P, Grygorczuk S, Pancewicz S, Świerzbińska R, Zajkowska J, Krawczuk K, et al. Evaluation of NSE and S100B in patients with tick-borne encephalitis. Brain Behav. 2018; 8(2) e01160.

12. Østergaard C, Johansen JS, Benfield T, Price PA, Lundgren JD. YKL-40 Is Elevated in Cerebrospinal Fluid from Patients with Purulent Meningitis. Clin Diagn Lab Immunol. 2002 May;9(3):598-604.

13. Craig-Schapiro R, Perrin RJ, Roe CM, Xiong C, Carter D, Cairns NJ, et al. YKL-40: a novel prognostic fluid biomarker for preclinical Alzheimer's disease. Biol Psychiatry. 2010 Nov 15;68(10):903-12.

14. Chen J, Ding Y, Zheng D, Wang Z, Pan S, Ji T, et al. Elevation of YKL-40 in the CSF of Anti-NMDAR Encephalitis Patients Is Associated With Poor Prognosis. Front Neurol. 2018; 9:727.

15. European Commission. Commission implementing decision (2012/506/EU) of 8 August 2012 amending Decision 2002/253/ EC laying down case definitions for reporting communicable diseases to the Community network under Decision No 2119/98/EC of the European Parliament and of the Council. Official Journal of the European Union. Luxembourg: Publications Office of the European Union. 27.9.2012. Available at http://eur-lex.europa.e/exUriSer/exUriServ.do? uri=OJ:L:2012:262:0001:0057:EN:PDF.

16. Czupryna P, Tarasow E, Moniuszko-Malinowska A, Pancewicz S, Zajkowska O, Targoński A, et al. MRI and planimetric CT follow-up study of patients with severe tick-borne encephalitis. Infect Dis (Lond). 2016;48(1):74-81.

17. Nordenbaek C, Johansen JS, Junker P, Borregaard N, Sorensen O, Price PA. YKL-40, a matrix protein of specific granules in neutrophils, is elevated in serum of patients with community-acquired pneumonia requiring hospitalization. J Infect Dis. 1999; 180:1722-1726.

18. Harvey S, Weisman M, O'Dell J, Scott T, Krusemeier M, Visor J, Swindlehurst C. Chondrex: new marker of joint disease. Clin Chem. 1998;44:509-516.

19. Johansen JS, Christoffersen P, Møller S, Price PA, Henriksen JH, Garbarsch C, Bendtsen F. Serum YKL-40 is increased in patients with hepatic fibrosis. J Hepatol. 2000; 32:911-920.

20. Johansen JS, Cintin C, Jørgensen M, Kamby C, Price PA. Serum YKL-40: a new potential marker of prognosis and location of metastases of patients with recurrent breast cancer. Eur J Cancer. 1995; 31A:1437-1442.

21. Cintin C, Johansen JS, Christensen IJ, Price PA, Sørensen S, Nielsen H J. Serum YKL-40 and colorectal cancer. Br J Cancer. 1999;79:1494-1499.

22. Grygorczuk S, Świerzbińska R, Kondrusik M, Dunaj J, Czupryna P, Moniuszko A. et al. The intrathecal expression and pathogenetic role of Th17 cytokines and CXCR2-binding chemokines in tick-borne encephalitis. J Neuroinflammation. 2018; 15, 115. 


\begin{tabular}{|c|c|c|c|c|}
\hline & \multicolumn{2}{|c|}{ Encephalitis } & \multicolumn{2}{|c|}{ Meningitis } \\
\hline Variable & Mean & SD & Mean & SD \\
\hline WBC (x $10^{9} /$ per microliter) & 8.48 & 3.5 & 9.18 & 3.007 \\
\hline $\mathrm{CRP}(\mathrm{mg} / \mathrm{dl})$ & 5.35 & 6.125 & 5.51 & 8.424 \\
\hline AST (IU/L) & 26.93 & 12.929 & 24.75 & 17.613 \\
\hline ALT (IU/L) & 46.93 & 42.433 & 34.33 & 28.404 \\
\hline CSF I - cytosis (cells/pL) & 137.63 & 147.872 & 115.93 & 83.244 \\
\hline CSF I - polynuclear cells (cells $/ \mu L$ ) & 69.25 & 151.195 & 54.4 & 60.422 \\
\hline CSF I - protein $(\mathrm{mg} / \mathrm{dL})$ & 60.19 & 22.466 & 73.94 & 28.707 \\
\hline CSF II - cytosis (cells $/ \mu \mathrm{L})$ & 23.71 & 21.670 & 44.25 & 24.981 \\
\hline CSF II - polynuclear cells (cells $/ \mu \mathrm{L}$ ) & 3.0 & 3.549 & 3.4 & 4.623 \\
\hline CSF II - protein $(\mathrm{mg} / \mathrm{dL})$ & 67.64 & 54.272 & 75.09 & 41.965 \\
\hline
\end{tabular}

Table 1. The laboratory parameters of patients included to the study

\begin{tabular}{|c|c|c|c|c|c|c|}
\hline & $\begin{array}{c}\text { Sample } 1 \\
\text { Mean } \pm \text { SD YKL- } \\
40(\mathrm{ng} / \mathrm{ml})\end{array}$ & & $\begin{array}{c}\text { Sample } 2 \\
\text { Mean } \pm \text { SD } \\
\text { YKL-40 } \\
(\mathrm{ng} / \mathrm{ml})\end{array}$ & & $\begin{array}{c}\mathrm{p} \\
\text { Sample } \\
1 \mathrm{vs} \\
\text { Sample } \\
2\end{array}$ & \\
\hline & serum & $\mathrm{CSF}$ & serum & $\mathrm{CSF}$ & serum & $\overline{\mathrm{CSF}}$ \\
\hline TBE & $102.38 \pm 63.2$ & $1475.37 \pm 913.86$ & $100.73 \pm 84.96$ & $827.68 \pm 529.71$ & $\mathrm{~S}$ & $<0.05$ \\
\hline$\underset{\text { I }}{\text { Group }}$ & $103.22 \pm 80.95$ & $1190.58 \pm 982.51$ & $99.99 \pm 112.09$ & $774.5 \pm 632.5$ & ns & ns \\
\hline $\begin{array}{c}\text { Group } \\
\text { II }\end{array}$ & $101.54 \pm 41.24$ & $1760.149 \pm 766.545$ & $101.48 \pm 48.5$ & $880.87 \pm 416.91$ & ns & $<0.05$ \\
\hline CG & $91.39 \pm 62.43$ & $311.53 \pm 240.59$ & & & & \\
\hline $\begin{array}{c}\text { p } \\
\text { Group } \\
\text { I vs. } \\
\text { Group } \\
\text { II }\end{array}$ & ns & $<0.05$ & ns & ns & & \\
\hline $\begin{array}{c}\text { p } \\
\text { Group } \\
\text { I vs. } \\
\text { CG }\end{array}$ & ns & $<0.05$ & & & & \\
\hline $\begin{array}{c}\mathrm{P} \\
\text { Group } \\
\text { II vs. } \\
\text { CG }\end{array}$ & ns & $<0.05$ & & & & \\
\hline
\end{tabular}

Table 2. Concentration of YKL-40 in serum and CSF of patients with TBE in the form of encephalitis (Group I) and meningitis (Group II) before (Sample 1) and after treatment (Sample 2) 
Figures

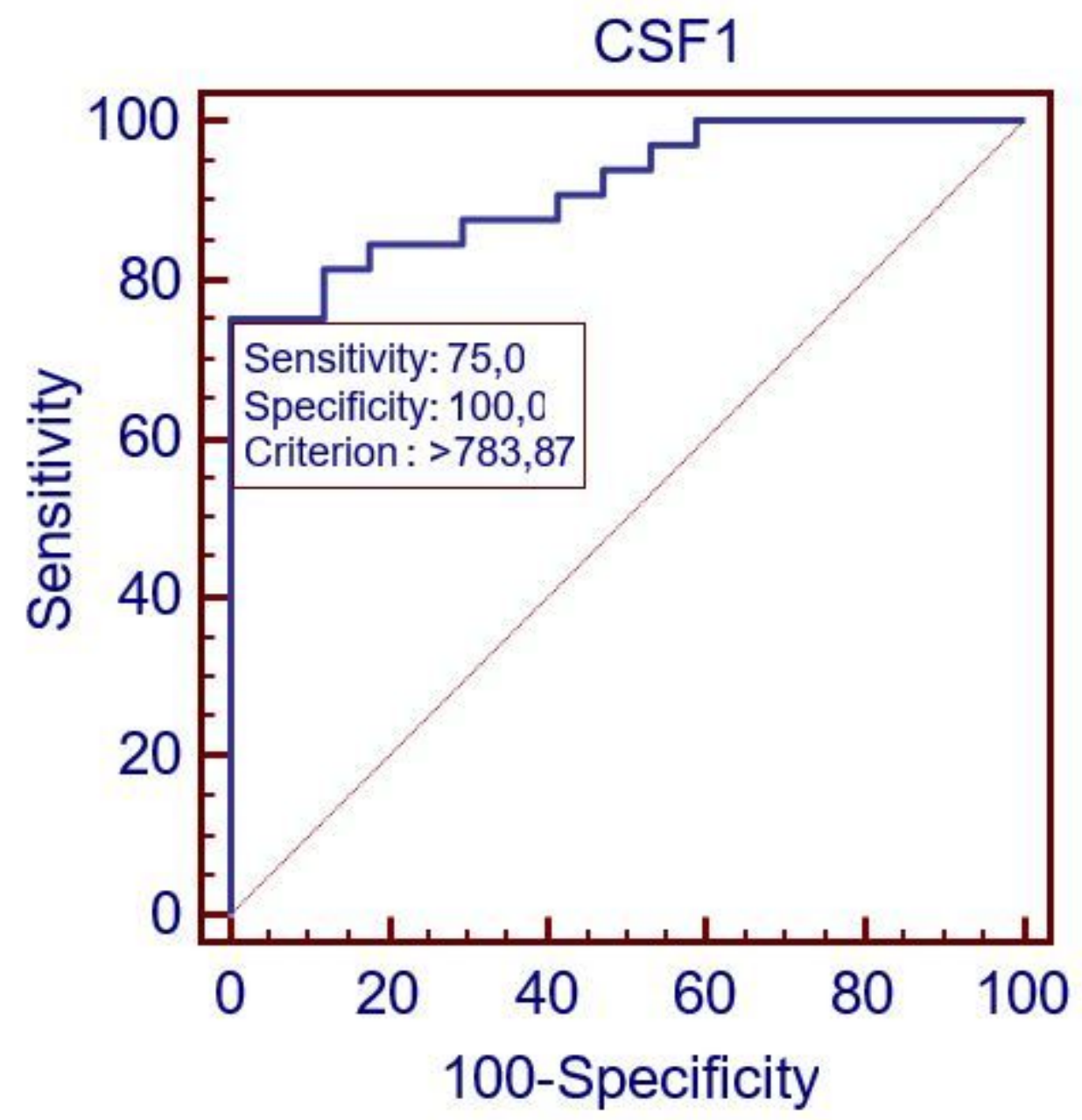

Figure 1

ROC curve analysis indicates that YKL-40 protein concentration in CSF differentiates TBE patients from CG. At the cut-off at $783.87 \mathrm{ng} / \mathrm{ml}$ specificity is $100 \%$ and sensitivity $75 \%$. AUC $=0.915, p<0.05$ (Fig. 1). 
CSF1

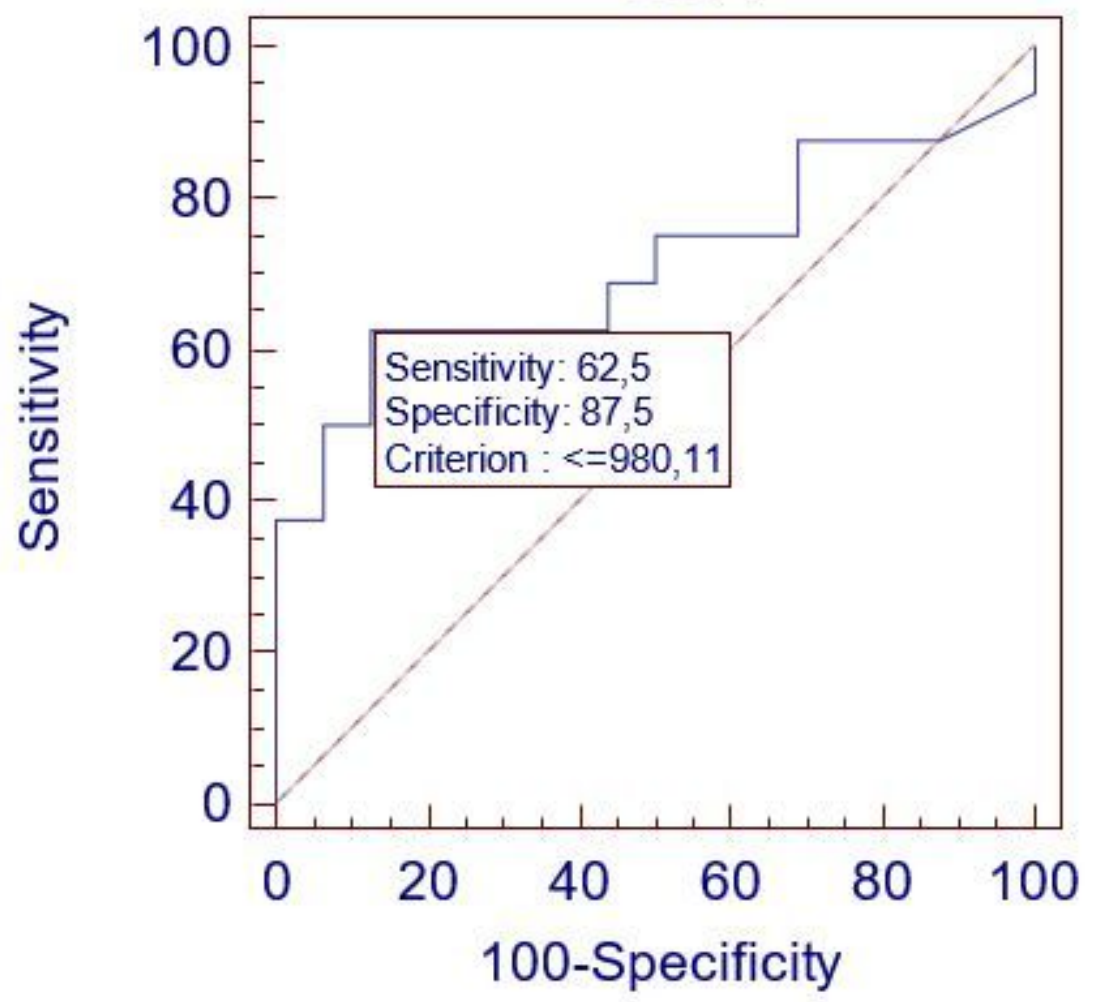

Figure 2

ROC curve analysis indicates that YKL-40 protein concentration in CSF differentiates meningitis and meningoencephalitis. At the cut-off $980.11 \mathrm{ng} / \mathrm{ml}$ specificity is $87.5 \%$ and sensitivity $62.5 \%$ AUC $=0.711$, p<0.05 (Fig. 2). 